Shlichta and R. A. Young, whom I thank.

JenNy PickWORTh GLUSKer

The Institute for Cancer Research

Fox Chase

Philadelphia

Pennsylvania 19111

U.S.A.

\section{Title Program}

American Crystallographic Association, Albuquerque, 3-7 April 1972.

A1 Electronic charge distributions and chemical bonding in simple molecules. P. E. CADE

A2 Determination of electron distributions by electron diffraction. $\mathrm{L}$. S. BARTELL

A3 Experimental spin densities. R. M. MOON

B1 Aspects of the electron density problem. Theoretical and experimental. W. N. LIPSCOMB

$B 2$ Alternatives in the comparison of experimental and theoretical charge densities. P. Coppens

B3 Charge density distribution in tetracyanoethyleneoxide by difference Fourier techniques and population refinement of the diffraction data. D. A. MATthews \& G. D. STUCKY

B4 MASSA (Post-deadline paper)

C1 The crystal structure of 1,3-O-Dmannitol borate monohydrate, [1,3-(hydroxyborylene)-D-mannitol monohydrate]. J. C. WALLACE

C2 The crystal structures of two Schiff's bases $-N$-benzylidene- $p$ bromoaniline and $N$-(2-naphthylmethylene)-p-bromoaniline. B. T. BLAYLOCK \& R. F. BRYAN

C3 The structure of two biologically interesting molecules. W. H. WATSON, J. E. WhINNERY \& K. C. Go

C4 Crystal and molecular structure of maytansine. R. F. BRYAN, C. J. GiLmore \& R. C. HALTIWANGER

C5 A comparison of two anthracene alkylating agents, ICR 489 and ICR 450. A. CHOMYN, J. P. GLUSKER, H. M. BERMAN \& H. L. CARRELL

C6 The structure and absolute configuration of pactamycin. X-ray analysis of desalipactamycate tosylate. D. J. DUCHAMP

C8 The crystal and molecular structure of alpha promedol alcohol. W. H. De CAmp \& F. R. Ahmed
C9 The crystal structure of heliotrine: A pyrrolizidine alkaloid (monoester). S. WODAK

C10 Crystal and molecular structure of barium 2-sulfuryl-L-ascorbate dihydrate. B. W. MCCLELLAND \& J. R. EINSTEIN

C11 Molecular and crystal structures of two compounds of pharmaceutical interest. D. B. Cosulich \& F. M. LOVELL

$D 1$ Refinement of the structure of sucrose. J. C. HANSON, L. C. SIEKER \& L. H. JENSEN

D2 The crystal structure and electron distribution of 1,1'-azobisdicarbamide and acetylene dicarboxylic acid. D. T. CROMER \& A. C. LARSON

$D 3$ The use of liquid-helium data in charge density studies: $p$-nitropyridine $N$-oxide. F. K. Ross \& P. COPPENS

E1 Crystal and molecular structure of 2,2,3,3,4-pentamethyl-1 - phenylphosphetane-1-oxide. A. FITZGERALD,C.N.CAUGHLAN \& G.D.S MITH

$E 2$ The crystal structure of bis-p-methoxy-phenyl 2,5-furandicarboxylate.W.C.BRYSON \& S.H.SIMONSEN

E3 The molecular structure of ethyl 2 - amino - 4,5,6,7 - tetrahydrobenzo[b] thiophene-3-carboxylate. S. H. SIMONSEN

E4 The structures of pyridine and isoquinoline fluvalenes. G. L. WHEELER \& H. L. AMMON

E5 Aminopentafulvenes. 5-ring bond lengths. N.M.R. coupling constants and rotational energies. $H$. L. Ammon, G. L. Wheeler \& L. A. Plastas

E6 The structure of exo-2-methoxy3-aza-4-keto-7,8-benzobicyclo[4.2.1] nonene. P. H. WATTS JR, H. L. AMMON, P. H. MAZZOCHI, H. J. TAMBURIN \& W. J. KOPECKY

E7 Crystal structures of two photoproducts of $\mathrm{N}$-chloroacetyltyramine. D. S. JONES \& I. L. KARLE

E8 The crystal structures of two antimalarials. L. A. Plastas \& H. L. AMMON

E9 The crystal and molecular structures of three compounds derived from a benzodiazepine. C. G. Childester, D. J. Duchamp \& J. SZMUSZKOVICZ

E11 The crystal structure of the orange molecular complex lumiflavin bis(naphthalene-2,3-diol) trihydrate. C.J.FRITCHIE JR, \& R.M.JOHNSTON

E12 Crystal structure of bis-10-methyl-i-alloxazine sesqui [silver(I)] perchlorate hydrate. G. D. SPROUL \& C. J. Fritchie JR
F1 The crystal structure of bikitaite. V. Kocman, J. C. RUCKLIDGE \& R. I. GAIT

F2 Tetrahedral sizes of orthopyroxenes and silicon-aluminum ordering. H. TAKEDA

F3 The crystal structure of scawtite. J. J. PLUTH \& J. V. SMITH

F4 The crystal structure of a titaniferous clinohumite. J. C. RUCKLIDGE \& V. KOCMAN

F5 The crystal structure of gladite, $\mathrm{PbCuBi}_{5} \mathrm{~S}_{9}$. I. Kohatsu \& B. J. WUENSCH

F6 Borate framework of boracite and its relationship to the ferroelectric effects. E. DOWTY \& J. R. CLARK

F7 Fully automated computer controlled laboratory. M. SLAUGHTER (Post-deadline)

G1 Concept of lattice. F. E. WANG \& J. R. HOLDEN

G2 Definition and determination of derivative lattices. A. D. MigheLL \& A. SANTORO

G3 Application of derivative lattices to the determination of coincidence-site lattices. A. SANTORO \& A. D. MigheLL

G4 Diamorphism in the three colored, crystallographic, point groups. D. HARKER

G5 Packing of tetrahedral molecules in molecular crystals. G. J. PIERMARINI \& S. BLOCK

G6 Structural relationships of compounds $A_{2} B X_{4}$ and $A_{2} B X_{3}$. W. EYSEL \& T. HAHN

G7 Domain patterns and crystal structure of $\mathrm{Pb}_{5} \mathrm{Ge}_{3} \mathrm{O}_{11}$, an opticallyactive ferroelectric. J. P. DOUGH erty, E. SaWAguchi, C. N. W. DARLINGTON \& R. E. NEWNHAM

G8 Neutron diffraction study of vanadium deuterides at various temperatures. M. H. Mueller, D. G. Westlake \& H. W. KNOTT

G9 Ferroelastic reorientation and detwinning in synthetic boracite. $\mathrm{L}$. P. Torre, S. C. Abrahams, R. L. BARNS \& K. NASSAU

G10 New ferroelastic crystals - predictions and verification. S. C. ABRAHAMS

G11 A disordered structure - octafluoronapththalene. G. S. MANDEL \& J. DONOHUE

$H 1$ The structure of (bicyclo[6.2.0]deca-2,4,6-triene) hexacarbonyldiiron, $\left(\mathrm{C}_{10} \mathrm{H}_{12}\right) \mathrm{Fe}_{2}(\mathrm{CO})_{6}$. F. A. CotTon \& B. A. Frenz

H2 The crystal structures of the green and the orange forms of bis $\left(5,5^{\prime}\right.$ diethylbarbiturato) bis (imidazole) nickel(II). B. C. WANG 
H3 The structure of $\mathrm{CoCl}_{2}$ (NO) $\left[\mathrm{P}\left(\mathrm{CH}_{3}\right)\left(\mathrm{C}_{6} \mathrm{H}_{5}\right)_{2}\right]_{2}$. C. S. PRATt, J. A. IBers, P. Farnham, C. Reed \& J. P. Collman

H4 The structure of nitrosylbis[o-phenylenebis (dimethylarsine)] cobalt diperchlorate. J. H. ENEMARK \& R. D. Feltham

H5 The crystal and molecular structure of potassium nitro(ethylenediaminetriacetato) cobaltate(III) 1.5hydrate. J. D. BELL \& G. L. BLACKMER

H6 The structures of $\mathrm{RhLCl}$ and [RhLCl(NO)] $\mathrm{PF}_{6}$, where $\mathrm{L}=$ $\mathrm{C}_{6} \mathrm{H}_{5} \mathrm{P}\left[\mathrm{CH}_{2} \mathrm{CH}_{2} \mathrm{CH}_{2} \mathrm{P}\left(\mathrm{C}_{6} \mathrm{H}_{5}\right)_{2}\right]_{2}$.

R. M. KIRCHNER \& J. A. IBERS

H7 The structure of the tetranuclear ruthenium carbonyl hydride, $\alpha-\mathrm{H}_{2} \mathrm{Ru}_{4}(\mathrm{CO})_{13}$. R. J. DOEDENS \& D. B. W. YAWNEY

H8 The crystal and molecular structure of neutral bis(ethylene-1,2dithiolene) complexes of $\mathrm{Pd}$ and $\mathrm{Pt}$ : Evidence for metal-metal bonding. J. S. KASPER, K. W. BROWALL, T. BURSH \& L.V. INTERRANTE

H9 The crystal structure of $\left\{\left[\mathrm{C}_{4}\left(\mathrm{CH}_{3}\right)_{4}\right]\right.$ $\left.\mathrm{CF}_{3} \mathrm{Pt}\left[\mathrm{P}\left(\mathrm{CH}_{3}\right)_{2} \mathrm{C}_{6} \mathrm{H}_{5}\right]_{2}\right\}\left[\mathrm{SbF}_{6}\right]$. D. B. Crump \& N. C. Payne

H10 Chelative addition of methylhydrazine to coordinated isocyanides: The structure of $\left[\left(\mathrm{C}_{5} \mathrm{H}_{11} \mathrm{~N}_{4}\right)\right.$ $\left.\mathrm{Pt}\left(\mathrm{CNCH}_{3}\right)_{2}\right]\left[\mathrm{B}\left(\mathrm{C}_{6} \mathrm{H}_{5}\right)_{4}\right]$. W. M. BUTLER, J. H. ENEMARK \& A. L. BALCH

H11 Sulfur dioxide attachment to halogen. M. R. SNOW \& J. A. IBERS

$H 12$ The crystal and molecular structure of $\mu$-(dimethylstannado) $-\mu$ hydridododecacarbonyl-trirhenium. B. T. HUIE \& C. M. KNOBLER

11 The structure of the tetrakis(succinimidato)cuprate(II) anion. L. SRINIVASAN \& M. R. TAYLOR

12 The crystal and molecular structure of di- $\mu$-(pyridine oxide)-bis[dichlorodimethylsulfoxidecopper (II)]. R. J. WILLIAMS, W. H. WATSON \& A. C. LARSON

13 The structures of two copper(II) complexes of 2-(2-aminoethyl)pyridine.P.SINGH, V.C. COPELAND, W. E. HATField \& D. J. HOdgSON

14 A complexion pair formed between an ether-coordinated potassium ion and bis(cyclooctate-traenyl) cerium (III) anion-The structure of $\left\{\mathrm{K}\left[\left(\mathrm{CH}_{3} \mathrm{OCH} \mathrm{CH}_{2}\right)_{2} \mathrm{O}\right]\right\}$

[ $\left.\mathrm{Ce}\left(\mathrm{C}_{8} \mathrm{H}_{8}\right)_{2}\right]$. K. O. Hodgson \& K. N. RAYMOND

15 Rotomers of a $\pi$-sandwich complex - The structure of $\mathrm{U}\left[\mathrm{C}_{8} \mathrm{H}_{4}\left(\mathrm{CH}_{3}\right)_{4}\right]_{2}$. K. N. RAYMOND \& K. O. HODGSON
I6 Identification and crystal structure analysis of a compound of heptavalent neptunium,

$\mathrm{LiCo}\left(\mathrm{NH}_{3}\right)_{6} \mathrm{~Np}_{2} \mathrm{O}_{8}(\mathrm{OH})_{2} .2 \mathrm{H}_{2} \mathrm{O}$.

J. H. BURNS, W. H. BALDWIN \& J. R. STOKELY

17 The aquated hydrogen ion, $\mathrm{H}_{7} \mathrm{O}_{3}^{+}$: A high precision neutron diffraction study of sulfosalicylic acid trihydrate (SSATH),

$\mathrm{C}_{6} \mathrm{H}_{3}(\mathrm{COOH})(\mathrm{OH}) \mathrm{SO}_{3} \mathrm{H} .3 \mathrm{H}_{2} \mathrm{O}$. J. M. Willams, S. W. Peterson \& H. A. LEVY

18 The crystal structures of $\mathrm{Na}_{2} \mathrm{HPO}_{4} . \mathrm{H}_{2} \mathrm{O}, \mathrm{Na}_{2} \mathrm{HPO}_{4} .7 \mathrm{H}_{2} \mathrm{O}$ and $\mathrm{Na}_{2} \mathrm{HPO}_{4} .12 \mathrm{H}_{2} \mathrm{O}$; order and disorder in hydrogen bonds. A. ZALKIN, H. RUBEN \& D. H. TEMPLETON

19 Lithium hydroxide monohydrate. P. A. Agron, W. R. Busing \& H. A. LEVY

110 The structure of organometallic derivatives of quinquevalent antimony and bismuth containing metal-oxygen-metal bonds. F. C. MARCH, G. FERguson, D. R. RIDLEY \& R. G. GOEL

111 The crystal structure of the barium thiocyanate complex of the cyclic polyether dicylohexyl-18-crown6 (isomer A). N. K. DALley, D. E. SMITH, R. M. IZATT \& J. J. CHRISTENSEN

112 The crystal and molecular structure of trinitrato-1,2-di(pyridine2-aldimino) ethane gadolinium (III). C. N. Caughlan, M. -ulHAQUe \& F. A. HART

$J 1$ Multiple diffraction in perfect and mosiac crystals. B. Post

J2 Experimental measurements of $X$-ray double reflection. J. A. MCGINNETY

J3 Anomalous diffraction by $\alpha$ quartz. R. D. DRAGSDORF \& J. MWANJE

J4 Thermal diffuse scattering in cubic powder patterns. C. B. WALKER \& D. R. CHIPMAN

J5 Calculation of the intensity of secondary scattering of $\mathrm{X}$-rays by non-crystalline materials: moving sample transmission geometry. C. W. DWIGGINS JR

J6 Measurement of the lattice parameters and interference distribution of small single crystals using a planar diffracted beam monochromator. C. $M$. MITCHELL

$J 7$ Use of digital microdensitometer in the analysis of X-ray powder diffraction photographs. C. F. PIHL \& R. L. BIEBER
J8 A computer-controlled X-ray powder diffractometry system with on-line data processing. $R$. C. Medrud, E. J. Harter, D. A. STEPHENSON \& W.T. KANE

J9 A disc oriented diffractometer control program. P. G. LENHART

$J 10$ A rapid data acquisition system for protein crystallography. N. H. XUONG \& W. VERNON

$K 1$ The crystal structure of the phase (Mg, Li)Al. S. SAMSON

K2 Crystal structure and electrical conductivity of the nickel platinum bronze, $\mathrm{Ni}_{0.25} \mathrm{Pt}_{3} \mathrm{O}_{4}$. D. CAHEN, J. A. IBERS \& R. D. SHANNON

K3 Crystal structures of some zirconium and niobium intermetallic compounds. A. E. DWIGHT

K4 The crystal structure of $\mathrm{Eu}_{3} \mathrm{As}_{4}$. M. L. SMART \& L. D. CALVERT

$K 5$ Crystallography of $\mathrm{Cu}_{3} \mathrm{SbS}_{3}$. E. MAKOVICKY \& B. J. SKINNER

$K 6$ The 'planar' peroxide group in ammonium persulfate. G. G. CHRISTOPH \& W. P. SCHAEFER

$K 7$ Phases and phase transformations of $\mathrm{Na}_{4} \mathrm{P}_{2} \mathrm{O}_{7}$. K. Y. LEUNG, D. DE LA MATter \& C. Calvo

$K 8$ Structure of paramagnetic betanickel iodate dihydrate. J. L. BERNSTEIN \& S. C. ABRAHAMS

$K 9$ The crystal structure of penoxtellurine diiodide. J.D. McCULLOUGH

$K 10$ The structure of gamma uranyl dihydroxide. S. SIEGEL, H. R. HoEKSTRA \& E. GeBERT

$K 11$ The crystal structure of CaKAsO ${ }_{4} \cdot 8 \mathrm{H}_{2}$ O. B. DickeNS \& W. E. BROWN

$K 12$ The crystal structure of $\left[\mathrm{SbCl}_{4}\right]+\left[\mathrm{Sb}_{2} \mathrm{~F}_{11}\right]-$ H. W. BAIRD \& H. B. MILLER

L1 The structure of flavodoxin at 25 A resolution. K. D. WATENPAUGH, L. C. SIEKER \& L. H. JENSEN

$\angle 2$ The structure of a bacterial ferredoxin. E. AdMAN, L. C. Sieker \& L. H. JENSEN

L3 The structure of t-butyloxycarbonyl-L-prolyl-L-prolylglycine monohydrate. J. M. HODSDON, B. SHAW, J.M. SCHURR \& L.H. JENSEN

L4 The confirmation of cyclo(L-proL-pro-L-hypro). G. KARTHA \& G. AMBADY

L5 Structure and conformation of orthorhombic L-cysteine. K. A. KERR

L6 X-ray crystal structure analysis of L-histidinium dihydrogen orthophosphate orthophosphoric acid. R. H. Blessing \& E. L. MCGANDY

L7 Alkaline phosphatase at $7.7 \AA$ resolution. J. R. KNOX \& H. W. WYCOFF 
L8 The crystal and molecular structure of 2-thioisouridine, a crowded nucleoside. L. M. JACOB, B. C. PAL \& J. R. EINSTEIN

$\angle 9$ Effects of sulfur substituents on base stacking and hydrogen bonding: crystal structure of 6-thioguanosine monohydrate. C. E. BUGG \& U. THEWALT

L10 Conformational studies of cyclic cytidine 2',3'-phosphate. C. L. Coulter \& D. K. LAvallee

$\angle 12$ The crystal structure of guanidinium 5-5-diethylbarbiturate dihydrate. R. J. McCluRe \& B. M. Craven

$M 1$ The molecular packing of steroids. D. A. NORTON \& W. L. DUAX

M2 Flexible $A$-ring conformations in 2,2-disubstituted steroids: normal chair and twist conformations. V. CODY, W. L. DUAX, F. E. DEJARNETTE, D. A. NORTON \& Y. OSAWA

M3 Ring $A$ conformations in three steroids. W. C. MARSH, G. FERGUSON \& D. F. RENDLE

M4 The crystal structure of a choleic acid - (deoxycholic acid/acetic acid, 1:1). B. M. Craven \& G. T. DETITTA

M5 The structure of $9 \alpha$-fluorocortisol. C. M. Weeks \& W. L. DuAX

M6 The crystal structure of $5,6,6 \mathrm{a}$, $6 \mathrm{~b} \alpha, 7,8,12 \mathrm{~b}, 13,14,14 \mathrm{a}-$ decahydro-3-ethoxy-10-methoxy, $6 \mathrm{a} \beta$, $12 \mathrm{~b} \beta, 14 \mathrm{a} \alpha$-tri-methylpycene and $4 b, 5,6,6 a, 9,10,10 a, 10 b \alpha, 11,12$ decahydro-2-methoxy-7(8H)oxo-4b $\beta, 6 \mathrm{a} \alpha, 10 \mathrm{a} \beta$-trimethylchrysene. B. L. Trus \& R. E. MARSH

M7 Thyroid hormone stereochemistry. I. The molecular structure of L-triiodothyronine. N. CAMERMAN \& A. CAMERMAN

M8 Crystal structure of zygacine acetonide hydroiodide acetonate. R. RESTIVO \& R. F. BRYAN

M9 The crystal and molecular structure of yohimbin hydrochloride. $G$. AMBADY \& G. KARTHA

M10 Crystal structure and stereochemistry of nupharidine hydrobromide. J. OHRT, R. Parthasarathy, R. T. LALONDE \& C. F. WONG

M11 Crystal structure of 2,6-bis(bromomethyl) -1,4-diphenylpiperazine. J. HOWATSON \& B. MOROSIN

N1 Hydrogen isotope fractionation, phase transformation and dynamic disorder in $\mathrm{YH}_{5} \mathrm{O}_{2}\left(\mathrm{C}_{2} \mathrm{O}_{4}\right){ }_{2} \mathrm{H}_{2} \mathrm{O}$; $\mathrm{A}$ neutron diffraction study. C. K. JOHNSON \& G. D. BRUNTON

N2 A neutron diffraction study of ferroelectric triglycine sulfate. M. I. KAY \& R. KLEINBERG
N3 Contrast in electron micrographs of crystal lattices. J. M. COWLEY, P. L. FEJES \& S. IIJIMA

N4 Electron-microscopic study of niobium oxides. S. IIJIMA

N5 Ring bending vibration and crystal structure of 1,1-cyclopentanedicarboxylic acid. T. N. MARGULIS

N6 Magnetic exchange in hydrobridged copper(II) and chromium (III) complexes. D. L. LEWIS, J. T. VEAL, W. E. HATFIELD \& D. J. HODGSON

N7 The high pressure synthesis, crystal structure, and properties of $\mathrm{CrP}_{4}$ and $\mathrm{MOP}_{4}$. W. JEITSCHKO \& P. C. Donohue

N8 Some measurements on the thermal expansion of $\alpha-\mathrm{Nb}_{2} \mathrm{O}_{5}$. G. M. WOLTEN

N9 Errors in quantitative measurements of local order. J. E. GRAGG JR, M. Hayakawa \& J. B. Cohen

$N 10$ Silica glass: $X$-ray diffraction evidence for a tridymite-like structure. J. H. KONNERT \& J. KARLE

N11 The structure of an ammonia sorption complex of zeolite $A$. K. SefF \& R. Y. YANAGIDA

N12 The crystal structures of arsonium and phosphonium cyclopentadienylides. G. Ferguson, F. C. MARCH \& D. F. RENDLE

O1 Generalized tangent formula. J. KARLE

O2 Strong enanthiomorph discrimination employing calculated cosine in variants and interacting classes of phases. H. HAUPTMAN \& W. L. DUAX

O3 Phase determination for valinomycin: strong enantiomorph discrimination. W. L. DUAX \& H. HAUPT MAN

O4 Structure of beryllium acetylacetonate solved by tangent refinement method. J. M. STEWARD \& B. MOROSIN

O5 Direct methods in neutron crystallography. The solution of the structure of the amino acid L-serine monohydrate. M. N. FREY, M. S. LehmanN, T. F. Koetzle \& W. C. HAMILTON

O6 The combination of anomalous dispersion methods with the tangent formula as a solution technique: Application to polar space groups. J. S. SHERfINSKI, R. E. MARSH \& T. J. KISTENMACHER

07 Neutron anomalous scattering. A study of the complex salt $\mathrm{NaSmEDTA} .8 \mathrm{H}_{2} \mathrm{O}$ using threewavelength data. T. F. KOETZLE \& W. C. HAMILTON
08 Some comments on weights and error analysis: A comparison between three independent structure refinements of L-asparagine monohydrate. W. C. HAMILTON, J. F. Verbist, T. F. Koetzle \& M S. LEHMANN

O9 Background determination for step-scan measured Bragg reflections. M. S. LeHMANN, W. C. HAMILTON \& F. K. LARSEN

010 Location of $\mathrm{Nd}$ dopant in fluorapatite. R.A. YoUnG \& P.E. MACKIE

011 System crystal: random file program system and crystallographic library for CDC 6000 series computers (Scope). J. W. EdMONDS

$P 1$ Crystal structure of 2,5-dimethyl2,5-hexanediol tetrahydrate: a water-hydrocarbon layer structure. G. A. Jeffrey \& M. S. Shen

$P 2$ The crystal structure of levopimaric acid, $\mathrm{C}_{20} \mathrm{H}_{30} \mathrm{O}_{2}$. I. L. KARLE

P3 Crystal structure and molecular geometry of hexahelicene derivatives. G. W. Frank, D. T. HefelFINGER, K. N. TRUeblood \& D. A. LIGHTNER

P4 The crystal structure of 9-dicyanomethylene-2,4,5,7-tetranitro-

fluorene: comparison with two related fluorene derivatives. J. Silverman \& N. F. YANNONI

P5 The crystal and molecular structure of bis-1,8-dimethylaminonaphthalene. H. EINSPAHR, R. E. MARSH, J. D. ROBERTS \& J.-B. ROBERT

$P 6$ The crystal and molecular structure of 3,3,8,8-tetracarbomethoxybicyclo[8.4.0]-tetradec-5-ene. J. M. JeNKS \& S. H. SimONSEN

$P 7$ The crystal and molecular structure of pyridoxol 5'-methylphosphonate. F. E. COLE, B. LACHMANN \& W. KORYTNYK

P8 The molecular structures of two phenylphosphonothioates. N. S. MANDEL \& J. DONOHUE

$P 9$ The structure of the solution photodimer of 3-phenyl-2-cyclopentenone. A.V. FratinI \& C.M. ShaW

$P 10$ The crystal structures of two thiolactams containing odd-membered rings. J. L. FLIPPEN \& R. D. GILARDI

$P 11$ The crystal and molecular structure of a 2- $H$ thiopyran $p$-bromobenzylester $\mathrm{C}_{20} \mathrm{H}_{22} \mathrm{O}_{4} \mathrm{NS}_{2} \mathrm{Br}$. A. E. SMITH

$P 12 \alpha, \alpha$-trehalose dihydrate, $\mathrm{C}_{12} \mathrm{H}_{22} \mathrm{O}_{11} .2 \mathrm{H}_{2} \mathrm{O}$. Three independent determinations. $G$. $M$. Brown, D. C. ROHRER, B. BerKING, C. A. Beevers, R. O. Gould \& R. SIMPSON 